\title{
IMPROVING STUDENTS' WRITING ABILITY THROUGH PROJECT BASED-LEARNING USING VISUAL MEDIA
}

\author{
Iis Harisma ${ }^{1}$, Ghina Ilmiah ${ }^{2}$, Yana ${ }^{3}$ \\ ${ }^{1}$ IKIP Siliwangi \\ ${ }^{2}$ IKIP Siliwangi \\ ${ }^{3}$ IKIP Siliwangi \\ 1 iisharisma98@gmail.com, ${ }^{2}$ ghinailmiah6@gmail.com, ${ }^{3}$ Yanamulyana86@ rocketmail.com
}

\begin{abstract}
The aim of this study is to know the improvement of students' writing ability through Project basedlearning using visual media in recount text at X Grades of students' Vocational High School in Cimahi. This study was Quantitative design, the sample of research consisted of 30 students. The instrument used in this research was written test. The written test was applied in pretest and posttest. The writing test was administrated as the instrument of the research. The result shown that the students' total score of pretest was 176, and then total score of posttest was 2222. It means that students' score increased. Then the data were analyzed using statistical formula of $t$-test computation The data were analyzed by using t-test as the significant level of $\mathrm{p}<0.05$ through SPSS version 15.0. Based on t-measure analysis show that $\mathrm{T}$-score $(9,589)>\mathrm{T}$-table $5 \%(2,045)$. It means that was significant so the Null Hypothesis (Ho) was rejected. It means that Project based- Learning using Visual Media has significant effect in improving students' writing ability.
\end{abstract}

Keywords: Writing, Project-Based Learning, Visual Media

\section{INTRODUCTION}

Nowdays, in globalization era, people create communication in written form a lot, people are more interesting to communicate with each other via gadget in social media. Social media as favorite tool of communication cause of practically, without going anywhere people can interact each other. People spend their time on their gadget, they write and browse information a lot in social media like types something in a blog, type a message via Whatsapp, Instagram, Line, BBM, or another application. Time by time communication more easily and practically through technology, it means that people have a good communication nowdays people must be ready to face the quickest expansion of world which force us to be able to communicate in English especially.

Based on the definition above, text can be in spoken or written form. They are like a letter, newspaper, magazine, etc. and the oral form like a speech, conversation, gossip, etc. A text is a sequence of paragraphs that represent an extended unit of speech and so many kinds of text. The text has to be understandable to make the communication run well. According to Carter, et al (cited in Apsari, 2017), writing is important for career and personal life because others will judge our thinking ability according to what we write and how we write it. It is supported by Mundriyah and Parmawati (2016) that witing skill is important, it does not get enough attention and proper time allocation in the teaching and learning process. According to Gebhard (1996 in Apsari, 2018), writing involves several components which have to be considered including 
word choice, use of appropriate grammar, syntax, mechanics, and organization of ideas into coherent and cohesive form.

Unfortunatelly, for a foreign language students writing is an activity that makes students worry, it seems Those statement supported by Hartawan et al., (2015) that writing is not easy skill to be masteredto be the most difficult language skill for language learners to acquire. In addition, they got only a few opportunities to explore their writing skill during the teaching-learning process. Although the teacher had tried some efforts to improve the condition of the writing class, they did not show a significant improvement. Furthermore, most of them did not show any interest in writing. It is in line with the statement of Sulistyani (2010) that writing is boring activity, and is not interesting (Sudilah, 2015). It is based on their research that in writing learning process, there are still many students who are difficult in deciding the topic and exploring their ideas in writing. The students suggest that it is uninteresting and boring activity.

Harmer (2007) states that the students' writing in English as the target language shows some indications that it needs improvement. Many of students are lack of confidence and lack of interest in writing. We have to proceed by any step mastering writing. No one comes into this world knowing how to write, how the regulation of the grammar, tenses itself. Seems nobody comes into the world without knowing something, how to catch a fly ball, mix paint, drawing a mountain, bake a cake, or drive a car. Several people are luckiest. They seem to acquire skill with very little effort. Most of us become expertness in what we choose to do through step by step learning reinforced by step practice.

Moreover, The practice design in teaching writing should make students interest and not boring. Project-based Learning integrates "learning by doing". Students not only learn knowledge and elements of the course curriculum, but also apply what they know to solve authentic problems and produce result that matter. PjBL refocuses education on the student, not the curriculum - a shift mandated by the global world. PjBL sometimes referred to a teaching technique, a teaching strategy or a learning model (Bas, 2011). In PjBL students not just learn something but they create something by their own creativity. Through Project Based-learning it can be effective to improve students' writing capabilities. According to Jonnasen and Rohrer-Murphy (1999) in Desrina Elita, Zainil (2012) by doing the project, the students are hoped to practice more in writing and enjoy in the process to improve their writing. Project based-learning is further motivated by activity theory. Activity theory places learning firmly in the perspective of contextual human praxis, and argues that conscious learning emerges from activity rather than as a precursor to it. When applied to education, activity theory helps educators to appreciate that the true focus of inquiry should be the everyday activity of persons acting in a setting.

Supported by Visual media that could build students' interest in learning. Orgunranti and Ihongbe defined "visual media aids as any picture, model, object, or device which provides tangible visual experience to the learner purposely for introducing, building up and enriching ideas". Visuals can be defined as things that can be seen such as posters, charts, chalkboard, flannel graph, flashcards, puzzles, objects - (real), projectors, cartoons, television, computer CD, internet and so on M.O.Ashokia, (2009 in Pratama, 2016) Improvisation/Teaching. According to Jannah in Pratama (2016) "Visual media is kinds of media that can be seen and can be touched by the teacher also the students related to the subject of the study".

The researchers interest to examine the Recount text by students' $X$ Grades of SMK Sangkuriang 1 Cimahi and want to know about the improvement of students' writing capabilities through project based learning using visual media. Recount text is a piece of writing 
that tells our experience in the past. Recount is kind of text about events in the order in which they occurred. The aim is to retell what happened in the past. According to Coogan (2006 in Siswita, Fenny \& Al Hafizh, 2013) recount text is written to retell event with the purpose of either informing or entertaining their audience or reader. It can be an interesting point to do this analysis. The researcher conduct this research under titled "Improving Students' Writing Ability Through Project Based-Learning Using Visual Media”.

\section{METHOD}

This study used quantitative research design which used one group pretest-posttest to conduct the research. This research was conducted at the First Grade of SMK Sangkuriang 1 Cimahi and used X AKL 1 as a sample of this research that consisted of 30 students. For the data collection of instrument, the researchers gave a pretest before treatment and asked students to write the text at least 150 words in 60 minutes. The posttest gave after treatment with the same criteria of written test. The treatment run 4 meetings, each meetings has 135 minutes. The researcherss have a lot of time to apply the Project based through visual media in every single treatment. And also the data instruments were valid based on the curriculum, and to makes it reliable, the researchers used inter-rater reliability and to analyze the students' score of pretest and posttest, the researchers used SPSS 15.0.

\section{RESULTS AND DISCUSSION}

\section{Results}

The researchers implemented this study to students at X Grades Vocational School. The researchers conducted the pretest to find out the students' writing ability before the treatment. The pretest was administered for 60 minutes. The mean of pretest was 58,70; the highest score was 76; the lowest score was 34; the standard deviation was 11.689. The researcher gave the posttest after the treatment to find out the progress and the improvement of students' writing after being taught through Project-based learning using visual media during fourth meeting. The mean of the posttest was 73.87; the highest score was 90; the lowest score was 50; the standard deviation was 7.200. The research also found out the distribution of the final score in the posttest. The result shown that the students' total score of posttest was 2222, and then total score of pretest was 1761. Based on the research question of the research about Is there any improvement or improvement of students' writing ability through Project based learning using visual media? The researcher found the several data as a result of the analysis through $\mathrm{N}$-gain result and t- test analysis.

Table 1 Gain Index Criteria

\begin{tabular}{ll} 
Gain Index & Criteria \\
\hline $\mathrm{g}>0,70$ & High \\
\hline $0,30<\mathrm{g} \leq 0,70$ & Middle \\
\hline $\mathrm{g} \leq 0,30$ & Low
\end{tabular}

Based on Gain Index Criteria, it shows that the data has a middle to High gain criteria. The data has gain index $0,30<\mathrm{g} \leq 0,70$. A few of the data on $0,30<\mathrm{g}$ but most of them on $\mathrm{g} \leq 0,70$. It means that there are improvement or differences between before and after treatment. Meanwhile, based on t-measure analysis show that of this research showed that T-score $(9,589)$ $>$ T-table 5\% (2, 045). It means that was significant so the Null Hypothesis (Ho) was rejected and Alternative Hypothesis (Ha) was accepted. Besides, in analyze t-test, t-score was higher 
than t-table. The score of t-test was 9, 589 and the t-table was 2,045 in the level of significant $5 \%(0,05)$. Based on the t-test result which obtain that Project Based Learning using Visual Media has significant effect in improving students' writing ability.

\section{Discussion}

The finding of the research indicated through Project-based learning using Visual Media, the students' writing ability has an improvement. In this research, the researchers found the appropriate match of method and media in teaching students' writing in order to improve the students' writing ability; the method and media that used were Project based-learning using visual media. In this research, researchers found there was a significant improvement in several aspect of students' writing, especially; vocabulary aspect and grammar/ language use aspect. Most of the students lacked of vocabulary, vocabulary is one crucial aspect to be considered in writing. Students got the lower score of vocabulary because they could not describe some details in developing the ideas in writing. But in the posttest students tried to write better than pretest, they tried to add some sentences, added new vocabularies, tried to write with the correct grammar to make improvement in their writing. The students wrote their ideas into sentence by sentence in order to make a paragraph more coherently. The improvement of students' writing in several aspect effected by every single treatment that was given. Students were instructed to pay attention in generic structure of text, they reminded to be careful the language features of the text (included the grammar), because of the major problems related to grammar were students' failure to use the correct tenses and their inability in terms of Subject-Verb agreement. Students confused when they have to change the tenses, and have to focus on writing while they were doing the posttest to keep, develop, and visualize their idea. Therefore, the result of posttest showed that language use aspect (grammar) showed a improvement.

During the treatment, researchers tried to create better improvement in students' writing ability of all writing aspect. It was proved by the data that was analyzed. The students' writing better and understandable than before. Since the students treated through Project based-learning that made the lesson more different than usual. Through project, students learned something by doing, they create and learn or learning by doing. Through Project Based-learning was an effective approach to improve students' writing capabilities. By doing the project, the students are hoped to practice more in writing and enjoy in the process to improve their writing. According to Railsback (2002: 9-10), there are some benefits of Project Based Learning (PjBL):

1. Preparing children for the workplace. Children are exposed to a wide range of skills and competencies such as collaboration project planning, decision making, and time management (Blank, 1997; Dickinson, et al, 1998),

2. Increasing motivation. Teachers often note improvement in attendance, more class participation, and greater willingness to do homework (Bottoms \& Webb, 1998; Moursund, Bielefeldt, \& Underwood, 1997).

3. Connecting learning at school with reality. Students retain more knowledge and skills when they are engaged in stimulating projects. With projects, kids use higher order thinking skills rather than memorizing facts in an isolated context without a connection to how and where they are used in the real world (Blank, 1997; Bottoms \& Webb, 1998; Reyes, 1998),

4. Providing collaborative opportunities to construct knowledge. Collaborative learning allows kids to bounce ideas off each other, voice their own opinions, and negotiate solutions, all skills that will be necessary in the workplace (Bryson, 1994; Reyes, 1998). 
5. Increasing social and communication skills. Students will learn how to communicate with other people in their group when they are doing a certain project. It will automatically increase their social and communication skills because they have to interact with different people which of course, have different ideas and point of view.

6. Increasing problem-solving skills. There could be some problems or misunderstandings among members of the group. They are demanded to solve their own problem (Moursund \& Bielefeldt).

7. Enabling students to make and see connections between disciplines. Each student has their own responsibility in finishing a project. It means that they have to do what group has told them to do.

8. Providing opportunities to contribute to their school or community. One kind of contributions is the product they have made.

9. Increasing self-esteem. Children take pride in accomplishing something that has value outside the classroom.

10. Allowing children to use their individual learning strengths and diverse approaches to learning (Thomas, 1998) and providing a practical, real world way to learn to use technology (Kadel, 1999; Moursund, Bielefeldt \& Underwood, 1997).

In the treatment, students asked to make their project related their ideas with creatively in visual form. Literally, Visual media is a thing that used to make students more interest in learning and easy to gain the idea. Visual media can be visualized as a picture, poster, slides, video, photograph, digital picture, video tape, chart, and so on. Orgunranti and Ihongbe stated that visual media aids as any picture, model, object, or device which provides tangible visual experience to the learner purposely for introducing, building up and enriching ideas. There were some benefit in teaching using visual media, this study proved the theory in Pratama which was explained by Morgan and Bowen that: a) Media vary pace of the lesson, b) Encourage the students to lift their eyes from books, which make it easier and natural for one to speak to another, c) Allows the teacher to talk less and more student participation, d) Enrich the classroom by serving the topic from the outside world which is made real and immediate by the picture or slides, e) Students' imagination more creative, learn the language easily and enjoyably through the visual media, f) It helps to teach all skill of English; listening, speaking, reading, and writing. As the result of this study, writer found that Project based-learning through Visual media gave a contribution in motivating students in writing class activity. It means students motivated to undertake a writing assignment because it allowed students more creative in learning the material. The final project of the students during the treatment showed a significant improvement from the pretest because they wrote text more specific, creative, and well-organized.

\section{CONCLUSION}

Refers to the findings and discussions above, the researchers conclude this study. First, the implementation of project based-learning using visual media improved the students' writing ability. Literally, Through Project- based using Visual media in teaching-learning process made a better improvement in all aspect of writing included; content, organization, language use, vocabulary, and mechanics. It could be seen on the students' work sheet, posttest and pretest data. Second, Project is a method or a technique in teaching that different with other techniques, method, or models. Project known as "Learning by doing. Students make a product/ project when they learn some materials. It added plus point of creativity of students' project. Based on experts that explained the benefits of implementation of project-based there was; a) prepared 
children for the workplace. Children was exposed to a wide range of skills and competencies such as collaboration project planning, decision making, and time management (Blank, 1997; Dickinson, et al, 1998), b) Increased motivation. Teachers often note improvement in attendance, more students participation, and greater willingness to do homework (Bottoms \& Webb, 1998; Moursund, Bielefeldt, \& Underwood, 1997). c) Connected learning at school with reality. Students retain more knowledge and skills when they are engaged in stimulating projects. With projects, kids use higher order thinking skills rather than memorizing facts in an isolated context without a connection to how and where they are used in the real world (Blank, 1997; Bottoms \& Webb, 1998; Reyes, 1998), and so on. Supported by the Visual Media that used in teaching learning process, it made students easier to express and visualize their ideas, it helped students to get the idea when they saw something like slides, picture, digital photograph, and many more kinds of projected visual media or non-projected visual media that used in the treatment before. Moreover, students could develop their idea and express it into a piece of written form, they easy to write sentence by sentence with the correct grammar without lost their ideas in writing. Students got a better improvement in writing; they got idea easily to write, and they understand the rules, structure, and language features of the text.

The researchers also have several suggestion for the future researcher to find out the effect of Project-based learning using visual media in different level of students, specific media and different kinds of text also.

\section{ACKNOWLEDGMENTS}

Alhamdulillah all gratitude to Allah S.W.T who gave His blessing to researcher, so researcher can finish this article with good health condition. Researchers would like to say the biggest thank you for researchers' article supervisors who always gave researcher support when conducting this research. Also, researcher would like to say thank you to IKIP Siliwangi which gave us opportunity to publish this article. Also for blind reviewer who were reviews this article as well as to the editorial team so this article can be published perfectly.

\section{REFERENCES}

Apsari, Y. (2017). The Use Of Picture Series In Teaching Writing Recount Text. Eltin Journal, Journal Of English Language Teaching In Indonesia, 5(2), 51-56.

apsari, Y. (2018). Reflective Reading Journal In Teaching Writing. Indonesian Efl Journal, 4(2), 39-47.

Bas, G. (2011). Investigating The Effects Of Project-Based Learning On Students ' Academic Achievement And Attitudes Towards English Lesson. Tojned: The Online Journal Of New Horizons In Education, 1(4), 1-15.

Desrina Elita, Zainil, D. R. (2012). Improving Students' Reading Comprehension Of Recount Text Trough Two Stay Two Stray Technique At Grade Viii 1 Of Smpn 2 Tilang Kamang Agam.

Harmer, J. (2007). The Practice Of English Language Teaching (Fourth Edition) (4th Ed.). Longman: Pearson.

Hartawan, A. E., Putrayasa, I. B., Artika, W., Pendidikan, J., Dan, B., Indonesia, S., ... Seni, D. (2015). Model Inkuiri Dalam Pembelajaran Menulis Teks Eksposisi Di Sma Negeri 1 Sukasada. Journal Universitas Pendidikan Ganesha Jurusan Pendidikan Bahasa Dan Sastra Indonesia, 3(1).

Mundriyah, M., \& Parmawati, A. (2016). Using Think-Pair-Share (Tps) To Improve Students'writing Creativity (A Classroom Action Research In The Second Semester Students Of Stkip Siliwangi Bandung). P2m Stkip Siliwangi, 3(2), 84-91. 
Pratama, S. (2016). The Effectiveness Of Using Photograph Towards Students' Skill In Writing Recount Text. In Mмum.

Siswita, Fenny \& Al Hafizh, M. (2013). Teaching Writing Recount Text To Senior High School Students By Using "Reading-Writing Connection Strategy." (September).

Sudilah. (2015). The effectiveness of Online Process Writing Portofolio Program to Improve the Writing Ability of S1 English Department Students Faculty of Teacher Training And Education - UT at Yogyakarta Distance Learning Program Unit. 2(2), 1-13.

Sulistyani, A. T. (2010). Dengan Metode Pembelajaran Kooperatif Think Pair and Share Melalui Media Majalah Dinding pada Siswa Kelas IX SMP Muhammadiyah, kec Kesesi. 